Vol. 2, No. 3, pp. 109-114, 2021

\title{
Training on Making Environmentally Friendly Clean Water Filters Using Bottles for Residents of Tegallega Village in Cianjur Regency
}

\author{
Rina Rindiani \\ Research Colaboratory Community, Bandung, Indonesia \\ Corresponding author email: rinarindiani@gmail.com
}

\begin{abstract}
Tegallega Village, Warung Kondang District, Cianjur Regency has a problem regarding the availability of clean water, the water used by residents comes from the Cimanceuri River or dug wells where the water is relatively cloudy, even though the use of dirty water has the potential to cause various health problems, such as cholera, dysentery, typhus, and tuberculosis and other diseases. The availability of clean water has always been one of the characteristics of community welfare. How not without clean water it is impossible to realize a prosperous society, a physically and mentally healthy society as a form of participation in developing public health. This activity method in community service uses a follow-up study method with a participatory approach in community service, the team conducts training on how to make simple water filtration that can be used as a source of clean water for families by using plastic bottle waste and other environmentally friendly materials that residents can find around environment in making the dirty water filter. The results of this Community Service Activity went smoothly and were greeted with great enthusiasm by the residents because the practice of making water purification equipment made with materials such as pebbles, coconut fiber, charcoal, fibers, and sponges functioned well from the water which was originally colored cloudy turns to be clearer and odorless.
\end{abstract}

Keywords: Water Filtration, Eco-Friendly, Training

\section{Introduction}

Water is one of the natural resources that has a very important function for human life and livelihood, as well as to promote general welfare so that it becomes the basic capital and main factor of development. This can be seen from the fact that $70 \%$ of the earth's surface is covered by water and two-thirds of the human body consists of water. The first requirement for the implementation of good health is the availability of adequate water in terms of quantity and quality, which must meet the requirements of cleanliness and safety (Gross, 2012).

Water has an important role in the life of all living things, including humans. Apart from being consumed, water is also used to support human life, such as the need for toilets (bathing, washing, latrine) and irrigation. Among these various uses, almost 85\% of water consumption is used for MCK (Mohan et al., 2021; Ali et al., 2018). Diseases arising from the water crisis, among others, cholera, hepatitis, polymearitis, typhoid, dysentery, trachoma, scabies, malaria, yellow fever, and intestinal worms (Collin 2009; Aarts et al., 2010).

Minister of Health Regulation RI No. 416/MENKES/PER/IX/1990 regarding Water Quality Requirements and Supervision, it is known that clean water has initial characteristics, namely odorless, colorless, tasteless, and not cloudy. The use of dirty water has the potential to cause various health problems. The provision of clean water for the community is not only the responsibility of the government and local governments. But it is also a shared responsibility, namely the Government (central and regional), the private sector, and the community. Each plays a role according to capacity, based on the awareness that the availability of clean water requires mutual awareness to keep existing water sources sustainable and not wasteful in using the existing clean water (Komarulzaman et al., 2017; Sari et al., 2020).

Water safety and quality are critical to human development and well-being. Providing access to clean water is one of the most effective instruments in promoting health and reducing poverty. As the international authority on public health and water quality, WHO leads global efforts to prevent the transmission of waterborne diseases. This is achieved by promoting health-based regulation to governments and working with partners to promote effective risk management practices to water suppliers, communities and households. (WHO 2020). The interest in the behavior of 
using clean water is the basis for someone's consideration to intend to do something. If he considers what he will do is important, then at the next stage he is supported by attitudes, perceived norms and personal conditions. Environmental intentions and barriers affect the behavior of using clean water in household settings (Azmanajaya et al., 2020; Windarto et al., 2019; Gui-quan and Junda, 2001).

The limited cost and the uneven distribution of PDAM's clean water supply lines to the residents of Tegallega Village have forced local residents to use the river water that flows through the village. In addition, residents also make shallow wells in almost every RW. The condition of cloudy river water is the main problem experienced by the villagers. Based on information provided by village officials, it is known that this condition is getting worse, especially during the planting season because the water source used will be mixed with soil and mud. The water will become increasingly cloudy, so a water purification method is needed so that the water becomes suitable for use (Zhang et al., 2019; Stern, 1996; Aspan et al., 2015).

The construction of large-sized sedimentation tanks cannot be realized due to limited land. Taking into account the field conditions, upflow sand filtering and stepwise pipe filtration filled with filter media were also used. Upflow operation can be used for filtering processes with fast flow rates (Zhang and Chen, 2009; Shi et al., 2014). Upflow sand filtering can also effectively reduce the content of metals such as iron and manganese. Filter media for filtering using shell charcoal, sand, and sponges. This system is designed with the convenience of local residents in mind to obtain filter materials. In addition, the construction of the filtering system is made as simple as possible so that it can be maintained, operated, and even duplicated by local residents.

Increased access to clean water and sanitation was found to have a positive effect on increasing the value of GRDP in districts/cities in Indonesia, increasing access to clean water, which was found to have an effect on reducing the level of population morbidity (Engel and Susilo, 2014; Odagiri et al., 2020). The study conducted by Alihar focused on the effect of access to clean water and improvement of environmental sanitation on infant mortality under five years of age and physical growth retardation (stunting). This study uses data from the 2009 and 2010 National Social and Economic Surveys. In general, the analysis in this study found that there is a negative correlation of increasing access to clean water and improving environmental sanitation to infant mortality under five years of age and slowing physical growth. The Tegallega Village Head Office Cianjur can be seen in Figure 1.

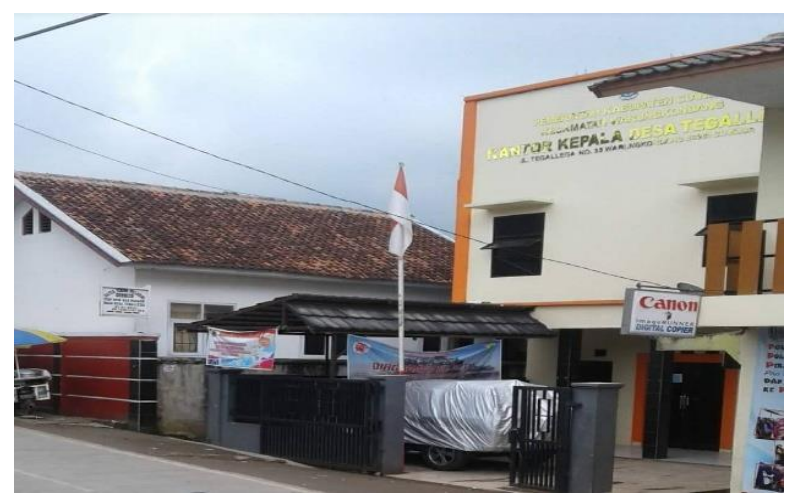

Figure 1 Tegallega Village Head Office Cianjur

The purpose of this community service is to help the residents of Tegallega Village, Warungkondang District, Cianjur Regency in fulfilling their integrity of clean and odorless water. Some of the things the team did in this service activity were providing training and practice on how to make water filtration with environmentally friendly and easy-to-find materials so that the community would be independent in providing clean water for their needs.

\section{Methodology}

Implementation of the service activity took place on November 15, 2021 at Tegallega Village, Warungkondang District, Cianjur Regency, West Java 43261 with the target of this community service program being local residents consisting of RT 01-05/RW 04 as many as 40 people (See Figure 2). 


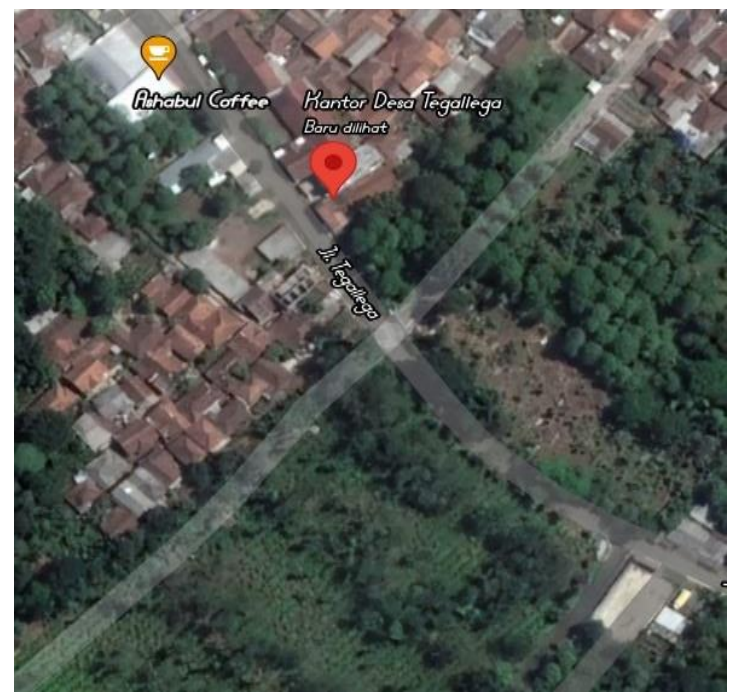

Figure 2. Map Location of Tegalega Cianjur

The method used in the implementation of this community service activity is socialization with counseling techniques in the form of lectures or presenting material in the form of theory and practical videos related to water filtration and questions and answers, including:

- Observation Stage

This activity was carried out as the beginning of the activity with the aim of obtaining a description of the environmental conditions around the village by holding a meeting with the Head of Tegallega Village, namely Mr. H Asep Nanang Haris

- Socialization Stage

In this stage, the service team will provide and explain the service plan that will be carried out so that time and various technical needs can be arranged in connection with the overall implementation of the training that was raised during the meeting with the village head.

- Implementation and Training Stage

The implementation of the training consists of 3 stages including::

- Sosialization

The community service program is carried out in the form of socialization to residents in Tegallega Village RT 01-05 / RW 002, Warungkondang District. The socialization was in the form of presenting material to participants related to the problems they faced. The material that will be delivered is expected to provide increased knowledge and understanding which can then be applied by the training participants.

- Discussion

After the material has been presented, it is followed by a discussion in the form of questions and answers between the presenter and the participants. Discussions are held so that participants better understand the material that has been presented. Through discussion, socialization is not just a transfer of knowledge but can share experiences and problems that are being faced by the training participants.

- $\quad$ Practice

The practice of making a simple water purifier. In this training on making water purifiers, we make videos on how to make them and show the videos during manufacturing practice, so that they can increase the knowledge and skills of the residents of Tegallega Village RT 01-05 / RW 002, Warungkondang District.

\section{Results and Discussion}

The training on the Use of Used Bottles as Simple Clean Water Filters for Tegallega Village, Warungkondang District, Cianjur Regency, was held on November 15-16 at the office of the head of Tegallega Village, Warungkondang District. Questions and answers about the use of used bottles as simple clean water filters filled in by the community service team (See Figure 3). 


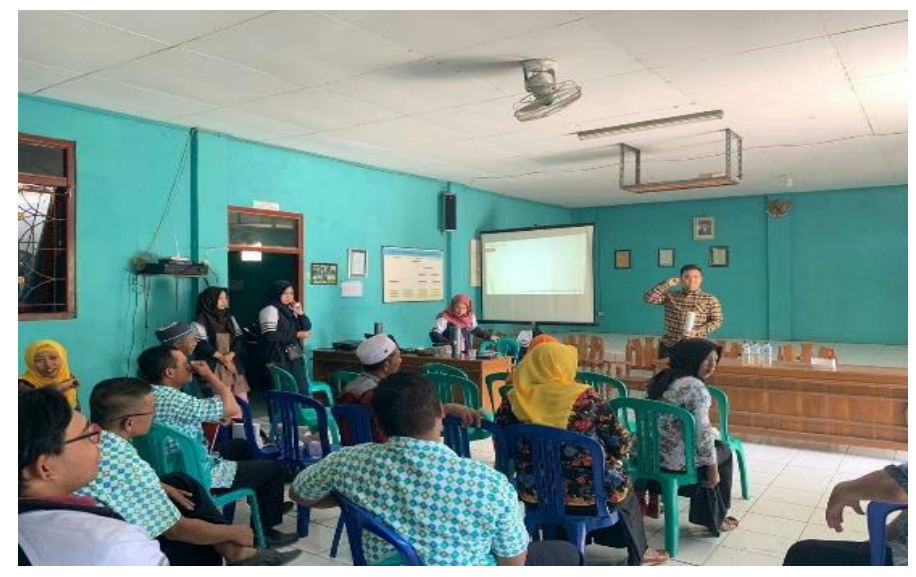

Figure 3. Training on Making Water Filters using Eco-friendly materials

The next event, continued with the practice of making used bottles as clean water filters. The materials used in this service are water, gravel, coconut fiber, charcoal, palm fiber and sponge. As for the implementation method of making a simple water filter, including:

1. A $1,500 \mathrm{ml}$ mineral water plastic bottle, used as a water filtering container. Gravel, as the first water filter. Coconut fiber, as a second level water filter Ijuk, as a third water filter. Charcoal, as the fourth water filter. Sponge, as the last or lowest water filter. The reservoir is useful for storing filtered water, the reservoir can use a bowl or other tool.

2. Working steps: To make sure the materials we use are really clean, wash all the materials to be used, then dry them. Take a $1,500 \mathrm{ml}$ used mineral water plastic bottle or a 1.5 liter size.

3. Cut the bottom using scissors or a cutter. Open the bottle cap, then place the water bottle in the reservoir, hold the mineral water bottle upside down so it doesn't collapse when filling the water filter materials.

4. Arrange the materials needed in order, namely gravel at the top, coconut fiber, charcoal, palm fiber, and finally a sponge. Place the reservoir under the bottle to collect the filtered water. Pour a few jars of dirty water slowly through the filter bottle. Continuously, pour the dirty water until the water that is accommodated turns clearer. If the filter results are still not clean, do the filtering again to get really clean water.

5. After filtering the water using a simple tool, the next task is to make a report on the observations. One part of the observation contains the results of observations and conclusions. Observation Results The results of water purification can be seen through the previous image. Where the water that was originally cloudy color turns clearer. This is because of the materials used, such as gravel, coconut husk, charcoal, palm fiber, and sponge.

6. The pebbles and coconut fiber used in this simple water purification tool are to filter large materials, for example: leaves, moss, algae, and others. Meanwhile, charcoal, fibers, and sponges function to filter or remove odors, colors, pollutants in water, as protection and exchange resins in water distillation or equipment (See Figure 4).

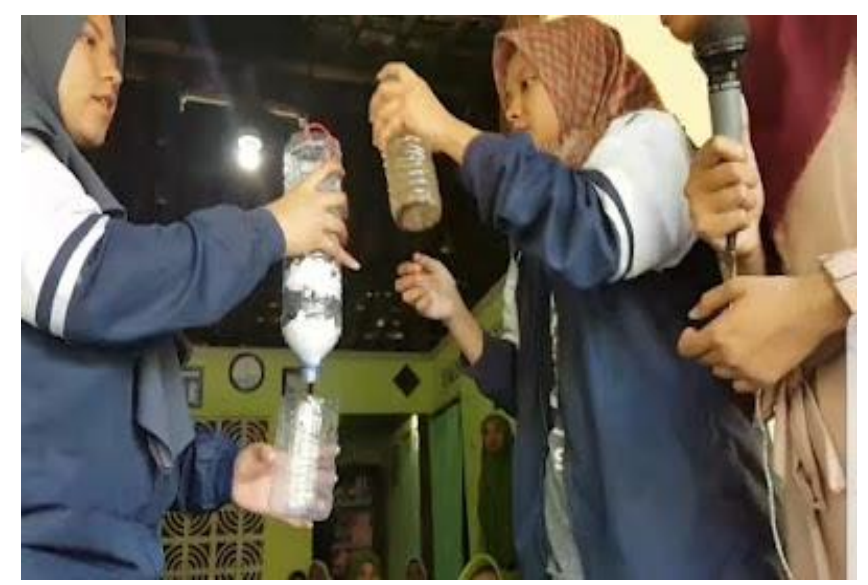

Figure 4 Water Filtration Manufacturing Practice

This activity was attended by 40 participants, where the participants were very enthusiastic about asking and answering the questions given by the organizing committee, then at the end of the implementation by giving souvenirs and taking photos with the socialization participants. During the service activities there were difficulties or obstacles 
in its implementation, namely where on the day of implementation many participants could not attend, this happened because of the Covid 19 pandemic. The second obstacle was the condition when delivering the material was still not conducive because some participants brought small children so that they often talk and play around his friend's training place which causes the focus of other participants on the delivery of the material to be disturbed, disturbing what is conveyed by the resource person.

\section{Conclusions}

The Community Service Activities carried out in Tegallega Village RT 01-05 / RW 002, Warungkondang District, went smoothly and were greeted with great enthusiasm by the residents. From the practice of making water purification equipment, it was found that the water which was originally cloudy in color turned out to be clearer and odorless because the materials used in the manufacture of this filter are environmentally friendly and easy to find.

\section{Acknowledgments}

It is hoped that with the training that has been given, partners can practice water purification equipment in their respective homes, and can transfer their knowledge to other residents and can be used optimally.

\section{References}

Aarts, M. J., Wendel-Vos, W., van Oers, H. A., Van de Goor, I. A., \& Schuit, A. J. (2010). Environmental determinants of outdoor play in children: a large-scale cross-sectional study. American journal of preventive medicine, 39(3), 212-219.

Ali, F., Lestari, D. L., Putri, M. D., \& Azmi, K. N. (2018). Identification of the characteristics and patterns of clean water consumption at the household level. Civil Engineering, 9(7), 1-12.

Aspan, H., Milanie, F., \& Khaddafi, M. (2015). SWOT Analysis of the regional development strategy city field services for clean water needs. International Journal of Academic Research in Business and Social Sciences, 5(12), 385-397.

Azmanajaya, E., Paulus, C. A., \& Paranoan, N. (2020, February). The Sustainability index of the provision of clean water treatment plants (IPAB) in supporting SDG 2030 programs for the availability and management of sustainable clean water in Soppeng Regency, South Sulawesi Province, Indonesia. In Journal of Physics: Conference Series (Vol. 1464, No. 1, p. 012052). IOP Publishing.

Collin, C. (2009). Biosand Filtration of High Turbidity Water: Modified Filter Design and Safe Filtrate Storage. Australia: University of Sydney.

Engel, S., \& Susilo, A. (2014). Shaming and sanitation in Indonesia: a return to colonial public health practices?. Development and Change, 45(1), 157-178.

Gross, C. M. (2012). Science concepts young children learn through water play. Dimensions of Early Childhood, 40(2), 3-11.

Gui-quan, X. U., \& Junda, C. H. U. (2001). Water Environment Improvement by Clean Water Diversion in Shanghai City [J]. Water Resources Protection, 3, 26-30.

Komarulzaman, A., Smits, J., \& de Jong, E. (2017). Clean water, sanitation and diarrhoea in Indonesia: Effects of household and community factors. Global public health, 12(9), 1141-1155.

Odagiri, M., Cronin, A. A., Thomas, A., Kurniawan, M. A., Zainal, M., Setiabudi, W., ... \& Pronyk, P. (2020). Achieving the Sustainable Development Goals for water and sanitation in Indonesia-Results from a five-year (2013-2017) large-scale effectiveness evaluation. International journal of hygiene and environmental health, 230, 113584.

Sari, E., Kristanto, G. A., \& Pratama, M. A. (2020, May). Green house gasses estimation from clean water production and supply sector in Depok City, Indonesia. In AIP Conference Proceedings (Vol. 2230, No. 1, p. 040015). AIP Publishing LLC.

Shi, S., Cao, J., Feng, L., Liang, W., \& Zhang, L. (2014). Construction of a technique plan repository and evaluation system based on AHP group decision-making for emergency treatment and disposal in chemical pollution accidents. Journal of Hazardous Materials, 276, 200-206.

Stern, D. I., Common, M. S., \& Barbier, E. B. (1996). Economic growth and environmental degradation: the environmental Kuznets curve and sustainable development. World development, 24(7), 1151-1160. 
Windarto, A. P., Siregar, M. N. H., Suharso, W., Fachri, B., Supriyatna, A., Carolina, I., ... \& Toresa, D. (2019, August). Analysis of the K-Means Algorithm on Clean Water Customers Based on the Province. In Journal of Physics: Conference Series (Vol. 1255, No. 1, p. 012001). IOP Publishing.

Zhang, P., Liao, Q., Yao, H., Huang, Y., Cheng, H., \& Qu, L. (2019). Direct solar steam generation system for clean water production. Energy Storage Materials, 18, 429-446.

Zhang, X., \& Chen, C. (2009). Emergency drinking water treatment in source water pollution incident-technology and practice in China. Frontiers of Environmental Science \& Engineering in China, 3(3), 364-368. 